\title{
Potential water requirements of increased ethanol fuel in the USA
}

\author{
Xiaowei (Vivian) Liu, S. Kent Hoekman ${ }^{*}$ and Amber Broch
}

\begin{abstract}
Background: To mitigate climate impacts associated with energy consumption, renewable fuel policies have been established in the USA that encourage production and use of corn ethanol. Current fuel usage of corn ethanol is approximately 15 billion gallons/year (57 billion liters/year), with nearly all of this in the form of E10 (10\% blend in gasoline). There is now interest in increasing fuel ethanol usage to achieve nationwide levels of E20 or greater. Due to lack of capacity and poor economics, cellulosic ethanol cannot contribute significantly to increased fuel ethanol production in the near term. Thus, rapid growth of fuel ethanol usage implies expansion of corn ethanol beyond current levels. The objective of this study was to assess the potential water requirements of expanding corn ethanol to provide for nationwide E20 fuel by 2025.

Methods: A simple modeling approach was used to assess the water requirements for producing 12.5 billion gallons (47.3 billion liters) corn ethanol in the baseline year of 2013 and 24.3 billion gallons (92.0 billion liters) in three future year scenarios of 2025. Irrigation water and process water were considered but not natural rainfall. Baseline inputs regarding corn acreage, crop yields, and irrigation patterns were obtained from the USDA's National Agricultural Statistics Service (NASS) for each of the 29 corn-producing states in the USA. The three future year scenarios differed in how the required expansion of corn cropping was allocated across the states, thereby resulting in different irrigation patterns.

Results: As a consequence of differing irrigation requirements, the water intensity of corn ethanol ( $L$ water $/ L$ ethanol) varied by approximately two orders of magnitude over the 29 corn-producing states. In the 2013 baseline, the water intensity of corn ethanol in lowa (with $1 \%$ irrigated corn acreage) was $5.5 \mathrm{~L} / \mathrm{L}$, while that in neighboring Nebraska (with $56 \%$ irrigated corn acreage) was $427 \mathrm{~L} / \mathrm{L}$. All three future year scenarios result in substantial increases in total volumetric water requirements-from 62 to $161 \%$ compared to the 2013 baseline.

Conclusions: Increasing ethanol blend fuels from E10 to E20 in the near future will require significant expansion of corn cropping in the USA, which will increase irrigation demands. The amount of increased water usage will depend upon the geographic distribution of the cropping expansion. Expansion into already water-stressed areas will exacerbate existing water concerns.
\end{abstract}

Keywords: Biofuel, Ethanol, E20, Irrigation, Water intensity, Corn agriculture

\footnotetext{
* Correspondence: Kent.Hoekman@dri.edu

Desert Research Institute, 2215 Raggio Pkwy, Reno, NV 89512, USA
} 


\section{Background}

For reasons of greenhouse gas (GHG) mitigation, energy security, and domestic energy supply, greater use of biofuels is being promoted in many countries throughout the world [1-4]. While the increase in biofuels is meant to realize these benefits, it is recognized that adverse resource and environmental impacts are also possible and should be mitigated [5]. For example, the US Environmental Protection Agency (EPA) has prepared a detailed report to Congress that discusses a wide variety of concerns associated with the two dominant biofuels used in the USA: biodiesel and ethanol [6]. In addition to water availability, these concerns include water quality, impacts on soils and ecosystems, air pollutant impacts, and other factors. A recent National Research Council (NRC) report has also focused on water implications of biofuels [7]. While these impacts and concerns are reasonably well understood and documented for the levels of biofuels being used today, there are serious questions about the implications of large increases in future amounts of biofuels. This study addresses the specific issue of increased water requirements necessary to support a doubling of ethanol fuel usage in the USA by 2025 .

\section{Biofuel regulatory requirements}

The 2007 US Energy Independence and Security Act (EISA) required the EPA to revise the existing Renewable Fuel Standard (RFS) program to increase the volume of renewable fuels included in the total US transportation fuel pool to 36 billion gallons per year (136 billion liters/year) by the year 2022 [8]. This socalled RFS2 program established volumetric requirements for four categories of renewable fuel: (1) conventional biofuel, (2) biomass-based diesel, (3) advanced biofuels, and (4) cellulosic fuels. Of these four, conventional biofuel has dominated, with most of this being ethanol produced via fermentation processes using corn starch as feedstock. According to EISA, the maximum volume of conventional biofuel contributing to the RFS2 volumetric requirements is limited to 15 billion gallons per year (57 billion liters/year) from the year 2015 onward. Current production of corn ethanol is approaching this statutory limit, with 14.8 billion gallons (56 billion liters) being produced in 2015 [9].

Today, essentially all US gasoline contains $10 \%$ ethanol (E10), with the ethanol component being produced nearly exclusively from corn. With total US gasoline consumption at just under 140 billion gallons per year, the demand for ethanol to satisfy nationwide E10 requirements is about 14 billion gallons per year. Additional corn ethanol is used to produce the relatively small amounts of E15 and E85 that are used in the USA. Although the RFS2 program originally anticipated substantial volumes of cellulosic ethanol to enter the marketplace between 2012 and 2022, this has not materialized. In recent testimony before the US House Committee on Energy and Commerce, the Deputy Administrator of the US Energy Information Administration (EIA) indicated that "the RFS2 program is not expected to achieve the legislated target that calls for 36 billion gallons of renewable motor fuel use by 2022," and that "virtually all of the projected shortfall is in the category of advanced biofuels, which includes cellulosic biofuels" [10]. Also, a recent report by the US Government Accountability Office (GAO) stated that "Current production of cellulosic biofuels is far below the statutory volumes and, according to experts, there is limited potential for expanded production to meet higher targets" [11]. As indicated in the 2016 Annual Energy Outlook forecast, the EIA now expects cellulosic ethanol to total less than 0.005 quadrillion BTUs by 2025, which translates to about 1.3 million gallons (4.9 million liters) [12]. This represents less than $0.1 \%$ of the cellulosic biofuel volume that was originally expected when the EISA was enacted in 2007.

Recently, there have been calls to consider higher ethanol fuel blends, such as E20 and above, for purposes of improving fuel economy and reducing GHG emissions [13-16]. Due to the immature status of cellulosic ethanol production and projections of very little additional cellulosic ethanol entering the market by 2025 , any large, near-term increase in fuel ethanol in the USA would require expansion of the current corn ethanol industry. Along with this expansion, water requirements, and other well-recognized natural resource, environmental and social concerns might also be expected to increase $[5,6]$.

\section{Current water requirements for corn ethanol}

Although water usage of corn-ethanol production plants is rather modest overall, this can still represent a significant additional demand in a local region. For example, it is estimated that a typical corn-ethanol plant (capacity of $100 \mathrm{mg} /$ year; $378 \mathrm{ml} /$ year) uses as much water as a community of 5000 people [17]. However, much more significant is the additional water required for crop irrigation, which exacerbates the general concerns about water availability in many regions [18]. A recent NRC report concluded that as of 2008, biofuels were a marginal additional stress on water supplies at the regional to local scale, but that significant acceleration of biofuels production could cause much greater water quantity problems, depending on where the crops are grown [7].

As shown in Fig. 1, production of corn (and corn ethanol) is concentrated in the Midwestern region of the USA. Although much of this corn is grown by rain-fed agriculture, a significant fraction utilizes irrigation. A 


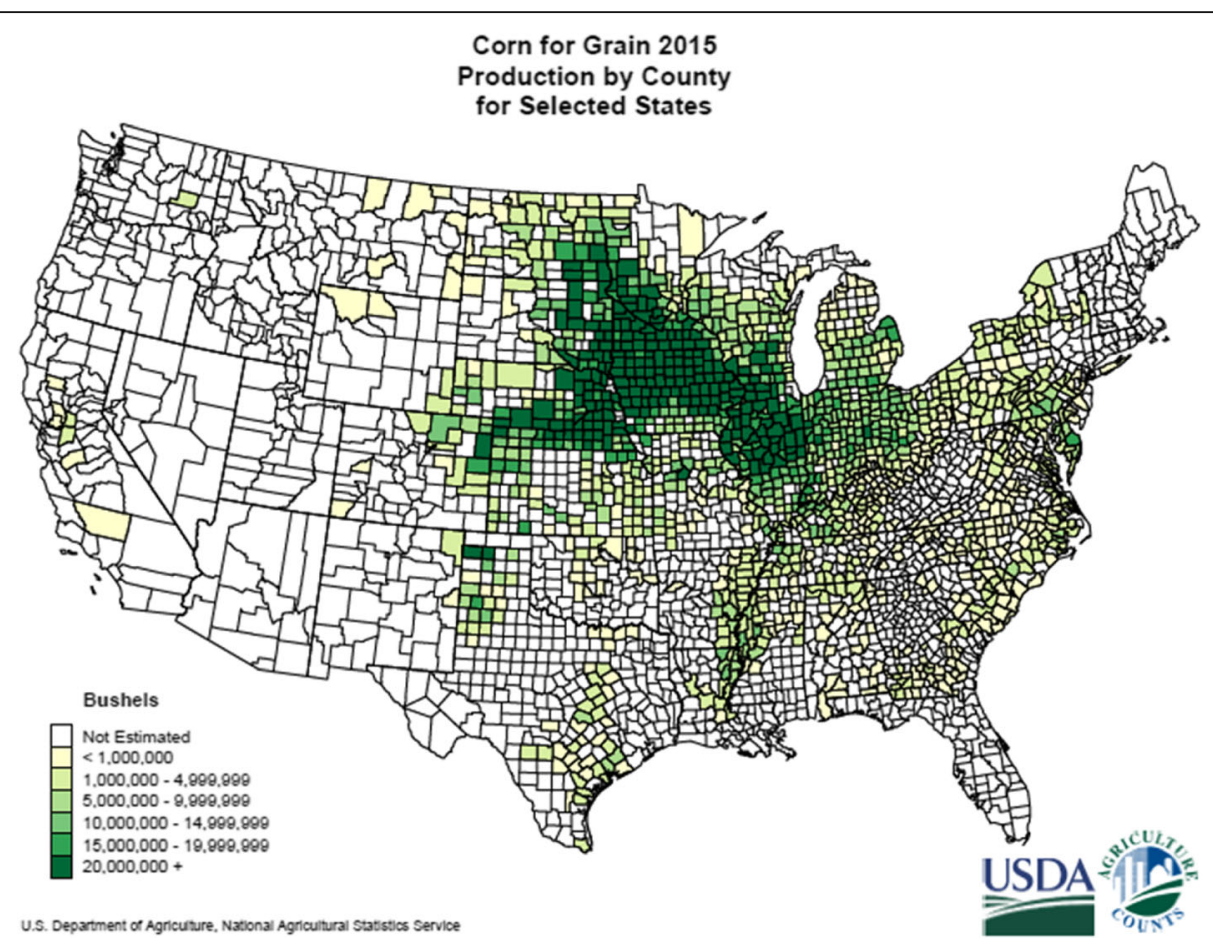

Fig. 1 Corn production by county in 2015. Taken from USDA-NASS: https://www.nass.usda.gov/Charts_and_Maps/Graphics/CR-PR-RGBChor.pdf

concern is that dramatic increases in corn production would entail greater use of irrigation, both by agricultural intensification in existing corn-growing areas and by expansion of corn cropping into drier areas.

Several studies have been conducted to quantify the amount of water required to produce corn-ethanol on a life-cycle basis [19]. One of the first comprehensive studies was published in 2009 and showed that water requirements varied drastically over the 19 corn-growing states that were investigated-from a low of $5 \mathrm{l}$ of water per liter of ethanol $(\mathrm{L} / \mathrm{L})$ in Ohio, to a high of $2138 \mathrm{~L} / \mathrm{L}$ in California [20]. The average value (weighted by 2007 ethanol production) was $142 \mathrm{~L} / \mathrm{L}$, although as the authors pointed out, national average values are not relevant in understanding bioethanol's water implications at a local scale. Also in 2009, Wu et al. published a life-cycle report confirming that crop irrigation is the most important factor determining total water consumption in providing corn ethanol in the USA and demonstrating the large regional variability of irrigation requirements [21]. Results showed that $70 \%$ of the corn used to produce ethanol in 2009 was grown in regions that required $10-17 \mathrm{~L} / \mathrm{L}$; whereas $19 \%$ of the corn was grown in regions that required over $300 \mathrm{~L} / \mathrm{L}$. Expressing water intensity in a different way, Dominguez-Faus et al. reported that the life cycle water consumption of ethanol produced from irrigated corn in Nebraska was equivalent to 50 gal per mile driven $(118 \mathrm{~L} / \mathrm{km})$ by a typical light-duty vehicle
[22]. Scown et al. determined the average water requirement of US corn ethanol to be $6.0 \mathrm{gal} / \mathrm{mile}$ traveled $(14.1 \mathrm{~L} / \mathrm{km})$, while a "high water use scenario," which included additional irrigation, had a water requirement of $79 \mathrm{gal} / \mathrm{mile}(186 \mathrm{~L} / \mathrm{km})$ [23]. Similarly, other researchers have investigated water requirements of ethanol derived from sugarcane grown in Brazil [24, 25].

The 2011 NRC/NAS report, Renewable Fuel Standard: Potential Economic and Environmental Effects of U.S. Biofuel Policy, summarized the consumptive water use (on a life-cycle basis) of corn ethanol compared to gasoline as reported in several research publications [5]. Because these life-cycle studies involved a number of different assumptions, a range of results was reported, rather than a single value. Results taken from five recent life-cycle assessment (LCA) studies are summarized graphically in Fig. 2 [21, 26-29]. As shown here, the consumptive water use of corn ethanol in the USA is 12 orders of magnitude higher than that of petroleumbased fuels.

A different way to assess water requirements of biofuels is based on the concept of water footprint (WF), which is defined as the total volume of freshwater used to produce goods and services for consumption [30-33]. The WF of a biofuel is dominated by the agricultural stage of the life cycle and consists of three components: (1) "green water," which refers to rainwater that is lost via evapotranspiration during crop growth; (2) "blue 


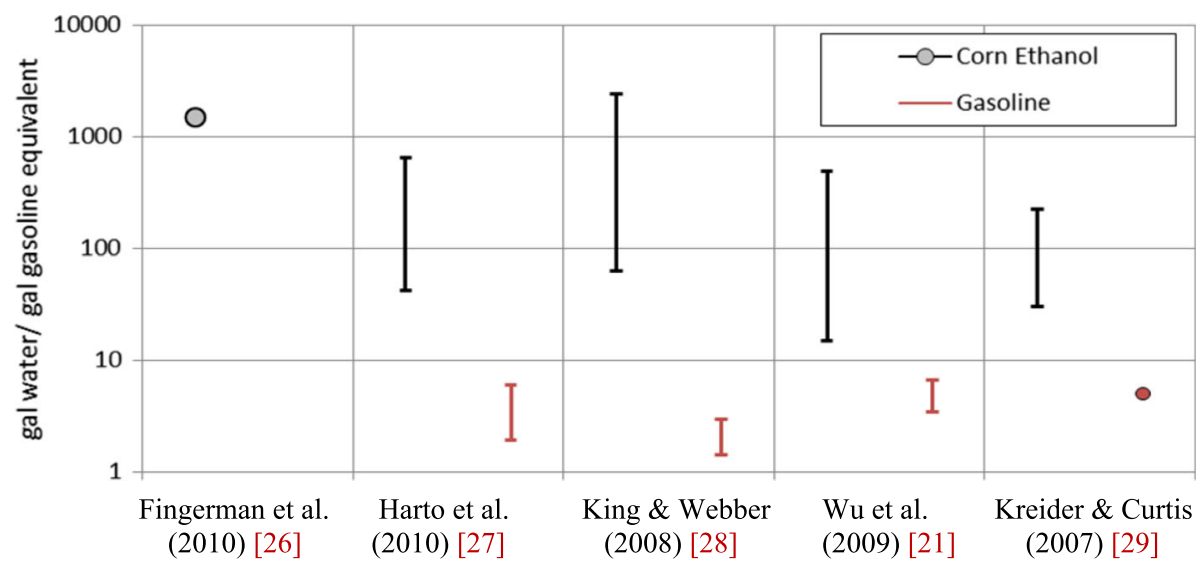

Fig. 2 Life-cycle consumptive water use of corn-ethanol and petroleum-derived gasoline

water," which refers to irrigation water (surface and groundwater) that is evaporated during crop growth; and (3) "gray water," which refers to water that becomes polluted during crop production (e.g., runoff and leaching of fertilizer).

While the WF concept is useful in fully understanding water requirements of different crops, climates, and locations, the blue water component requirements are of greatest interest in addressing the issue of increased corn cropping for ethanol production. A fundamental question is how much more irrigation water is necessary to grow sufficient corn to enable doubling of ethanol fuel usage, while continuing to meet the current food and feed demands for corn. Because much of the future corn expansion is expected to occur on land that requires irrigation, the water consumption of marginal corn ethanol will increase [34]. The question of where this additional irrigation occurs is critical, as more severe water stresses exist in some locations than others.

Simple LCA-derived metrics regarding the average water requirements to produce 1 gal of ethanol are not very useful for decision-making because they lack detailed location-specific information needed to fully understand local impacts. Additional tools and metrics are needed to relate the total water use with relevant environmental impacts. Pfister et al. have developed and applied the concept of water stress index (WSI) to weight water consumption in a particular location as a function of water scarcity in that location $[35,36]$. Other researchers have also attempted to apply various metrics for characterizing water scarcity, water stress index, and environmental flows to assess the environmental significance of ethanol's water requirements $[37,38]$. While assessing locationspecific impacts of biofuel production is important for policy decisions, this is beyond the scope of the present study, where we focus only on the volumetric water requirements of expanded corn cropping in the USA. Our objective is to determine bounding estimates of volumetric water requirements that would be associated with increasing corn ethanol production to provide nationwide E20 fuel by 2025 .

\section{Methods}

To produce substantially more corn ethanol in the USA will require increased water usage. The magnitude of this increase depends largely on where the additional corn is grown and the extent of irrigation needed to support this growth. To assess the potential water requirements of increased corn ethanol production, we conducted simple modeling exercises, utilizing data available from USDA's National Agricultural Statistics Service (NASS) [39]. This work did not involve calculation of water footprints or formal LCA modeling of detailed scenarios, but rather, explored a range of corn expansion scenarios to provide insights into potential water requirements of increased ethanol fuel.

The year 2013 was chosen as the baseline because this is the most recent year for which NASS includes reasonably complete irrigation data. In 2013, the total amount of corn ethanol produced in the USA was 12.5 billion gallons (47.3 billion liters). The water requirements to produce this ethanol were assessed by state, both in the 2013 baseline case and in three future-year scenarios. All three future scenarios were for the year 2025 and assumed a total ethanol production of 24.3 billion gallons (92.0 billion liters), which is approximately double the value in 2013. This amount of ethanol is estimated to be sufficient to provide nationwide E20 fuel in 2025. The value of 24.3 billion gallons represents $20 \%$ (by volume) of the 
total motor gasoline projected by EIA in their most recent Annual Energy Outlook report [12]. It is important to recognize that doubling of corn ethanol does not imply doubling of corn acreage, as only a fraction of the total corn crop $(\sim 40 \%)$ is used to produce ethanol. In all scenarios, the amount of corn needed to satisfy current demands for food and feed is held constant.

\section{Scenario definition}

The NASS database includes information about corn production on irrigated and non-irrigated land in 29 corn-growing states. In the 2013 baseline case, the 12.5 billion gallons of corn ethanol was assumed to be produced from each state in proportion to that state's corn production. This assumption is not strictly correct, as a greater fraction of the corn crop is used to produce ethanol in some states than in others. The three futureyear scenarios are described below.

2025 scenario A This scenario utilizes "uniform expansion" of corn in all 29 states. The amount of corn grown in each state is simply scaled up so that total corn production is sufficient to generate 24.3 billion gallons of ethanol in 2025. In each state, corn is grown on both irrigated and non-irrigated land, in the same proportion as in 2013. This may be regarded as a "business as usual" growth plan to satisfy the increased ethanol demand. However, with respect to water requirements, this scenario is probably overly conservative, as the large expansion of agricultural areas necessary to support this additional corn cropping is likely to encompass drier areas that will require increased irrigation.

2025 scenario B This scenario utilizes " $50 \%$ expanded irrigation" to grow additional corn needed to provide 11.8 billion gallons more ethanol than in 2013. It is assumed that both the original 12.5 billion gallons and the additional 11.8 billion gallons of ethanol are produced in the 29 corn-growing states, in proportion to their 2013 production amounts (as in scenario A.) In this case, however, it is assumed that $50 \%$ of the additional corn is produced on irrigated land, while the other $50 \%$ is produced on non-irrigated land. This may be regarded as a "worst case" scenario, as it assumes very large increases in irrigation will be required to grow the required amount of corn.

2025 scenario $C$ This scenario assumes that all expanded corn growth to produce the additional 11.8 billion gallons of ethanol by 2025 occurs in the top 12 corn-growing states. This "Midwest expansion" scenario also assumes that irrigated acreage in each of the 12 states is increased by 10 percentage points over the irrigated acreage in the baseline case. For example, $10 \%$ of the corn acreage in South Dakota was irrigated in 2013; thus, in the Midwest expansion scenario, it is assumed that $20 \%$ of South Dakota's corn acreage is irrigated in 2025. This may be regarded as a "middle ground" or "most likely" scenario. The vast majority of total US corn is already grown in these 12 states (>85\%), largely because their soils and climates are most suitable. Thus, it is reasonable to intensify corn agriculture in these areas to satisfy the additional ethanol demand. However, such intensification is likely to require at least a modest increase in irrigation; hence, the 10 percentage point increase in irrigated acres assumed in each of these 12 states.

The three future-year scenarios described above are summarized and compared with the 2013 baseline in Table 1. This shows that while the total acreage expansion is similar in all three future scenarios, the amount of additional irrigation is quite different among the three. The increase in irrigated acres is least in scenario A (14\% of additional acres are irrigated) and greatest in scenario B (59\% of additional acres are irrigated). Because of this, total water requirements are also expected to be least in scenario A and greatest in scenario B.

\section{Input assumptions and datasets}

Total corn production and irrigation data for all corn-producing states in 2013 were collected from the NASS database. These data were used to compute water intensity (gal/gal) and total water requirements (gal/y) of ethanol production in each of the 29 corngrowing states in the 2013 base case. All water used

Table 1 Description of scenarios investigated in this study

\begin{tabular}{lllllll}
\hline Scenario & Year & $\begin{array}{l}\text { Total ethanol, } \\
\text { billion gallons }\end{array}$ & $\begin{array}{l}\text { Non-irrigated acres for } \\
\text { ethanol (million) }\end{array}$ & $\begin{array}{l}\text { Irrigated acres for } \\
\text { ethanol (million) }\end{array}$ & $\begin{array}{l}\text { Total acres for } \\
\text { ethanol (million) }\end{array}$ & $\begin{array}{l}\text { \% of additional acres } \\
\text { on irrigated land }\end{array}$ \\
\hline Baseline & 2013 & 12.5 & 23.9 & 4.1 & 28.0 & - \\
$\begin{array}{l}\text { A-uniform } \\
\text { expansion }\end{array}$ & 2025 & 24.3 & 38.7 & 6.6 & 45.4 & 14.4 \\
$\begin{array}{l}\text { B-50\% expanded } \\
\text { irrigation }\end{array}$ & 2025 & 24.3 & 30.9 & 14.4 & 45.4 & 59.2 \\
$\begin{array}{l}\text { C-Midwest } \\
\text { expansion }\end{array}$ & 2025 & 24.3 & 37.0 & 8.5 & 45.5 & 25.1 \\
\hline
\end{tabular}


to irrigate corn acreage is attributed to the ethanol produced from this corn. Several other important assumptions were made in the calculation process to assess future-year scenarios:

- The productivity of corn agriculture (bushels/acre) is steadily improving in the USA [40]. We assumed a $1.0 \%$ increase in corn yield per year from 2013 to 2025.

- The efficiency of ethanol production (gallons/ bushel) in commercial corn ethanol plants is steadily improving [40]. We assumed a linear increase from $2.8 \mathrm{gal} / \mathrm{bushel}$ in 2013 to $3.0 \mathrm{gal} / \mathrm{bushel}$ in 2025 .

- The efficiency of water usage within corn ethanol plants is steadily improving. We assumed that the average water usage of $2.70 \mathrm{gal}$ water/gal ethanol in 2013 [41] is linearly reduced to $2.43 \mathrm{gal} / \mathrm{gal}$ by 2025 (10\% reduction).

- Corn yield (bu/acre) is known to vary between irrigated and non-irrigated land. However, the NASS database does not include separate yields for many states of interest. For the 2013 baseline scenario, we used statewide average corn yields, which include irrigated and non-irrigated production. Future yields were scaled up by $1 \%$ per year, but no adjustments were made to account for variations in yield due to increased irrigation.

The key model input parameters of corn yields, ethanol yields, and ethanol plant water usage are summarized in Table 2.

\section{Model calculations}

Because each scenario has different assumptions about the percentage of irrigated cropland and other model inputs, the calculation of corn production and water use is somewhat different for each of the four scenarios. The calculation process is described below in detail for the baseline scenario, and differences for future scenarios $\mathrm{A}$, $\mathrm{B}$, and $\mathrm{C}$ are briefly explained.

Table 2 Model input parameters used in baseline and future-year scenarios

\begin{tabular}{lll}
\hline Parameter & 2013 & 2025 \\
\hline Corn ethanol volume, bg & 12.5 & 24.3 \\
Corn yield, bushels/acre ${ }^{a}$ & $\mathrm{X}$ & $1.12 \mathrm{X}$ \\
Ethanol yield, gallons/bushel $^{\text {Ethanol plant water usage rate, gal water/gal ethanol }}$ & 2.8 & 3.0 \\
\hline
\end{tabular}

${ }^{a}$ Corn yields for each state are obtained from NASS database

\section{Baseline scenario}

To determine the amount of ethanol produced by state, the percentage of total corn production in each state is first calculated by dividing that state's corn production by total national corn production:

$$
\begin{aligned}
& \text { Corn produced by state (\%) } \\
& =\frac{\text { Corn production by state (bushels) }}{\text { Total US corn production (bushels) }}
\end{aligned}
$$

The amount of ethanol allocated to each state is calculated by multiplying the state's corn percentage by 12.5 billion gallons:

$$
\begin{aligned}
& \text { Ethanol produced by state (million gallons) } \\
& =\text { Corn produced by state }(\%) \times 12,500 \text { (million gallons) }
\end{aligned}
$$

As only a fraction of the corn crop is used to produce ethanol, it is necessary to determine the corn acreage in each state that is attributed to ethanol production. To do this, the amount of corn required to produce the specified amount of ethanol for a given state is calculated as follows:

Corn produced for ethanol (million bushels)

$=$ ethanol produced $($ million gallons $) \div$ ethanol yield

$$
\left(\frac{\text { gallons }}{\text { bushel }}\right)
$$

Then, the amount of corn cropland required to produce a given state's amount of ethanol is calculated as follows:

$$
\begin{aligned}
& \text { Corn cropland for ethanol corn (acres) } \\
& =\text { corn produced for ethanol (million bushels }) \div \\
& \text { corn yield }\left(\frac{\text { bushels }}{\text { acre }}\right)
\end{aligned}
$$

It is assumed that ethanol is produced from corn grown on both irrigated and non-irrigated land in each state. The total water applied to corn that is used to produce ethanol comes from irrigation of specific cropland. The acreage of irrigated land in a given state is calculated as follows:

$$
\begin{aligned}
& \text { Percentage of irrigated land }(\%) \\
& =\frac{\text { Irrigated corn cropland (acres) }}{\text { Total harvested corn cropland (acres) }} \\
& \text { Irrigated land for ethanol corn (acres) } \\
& =\text { Percentage of irrigated land (\%) } \times \\
& \text { corn cropland for ethanol corn (acres) }
\end{aligned}
$$

The amount of water used to irrigate corn is reported in the NASS database as acre feet per acre. One acre foot of applied water is equivalent to 325,900 gal $\left(1.234 \times 10^{6} \mathrm{~L}\right)$. Thus, the total water applied for growing corn that is used to produce ethanol in each state is calculated as follows: 
Total water applied (gallons) $=$ water applied (acre-feet) $\times 325,900\left(\frac{\text { gallons }}{\text { acre- } \mathrm{ft}}\right) \times$ irrigated cropland $($ acres $)$

The water intensity of corn ethanol that is attributed to feedstock production within each state is defined as the amount of irrigation water used per gallon of ethanol produced in the state.

$$
\begin{aligned}
& \text { Water intensity for feedstock }\left(\frac{\text { gallon water }}{\text { gallon ethanol }}\right) \\
& =\frac{\text { Total water applied (gallons) }}{\text { Total ethanol produced (gallons) }}
\end{aligned}
$$

Note that this study focuses on water applied by irrigation (blue water), while water provided by rainfall (green water) is not considered. Therefore, this assessment does not provide a complete water footprint, as commonly defined [30, 31, 42].

Finally, the total water intensity of ethanol in each state is calculated as the sum of the water intensity for feedstock production and the water intensity for ethanol production. For ethanol fuel production, the national average of $2.70 \mathrm{~L} / \mathrm{L}$ (in 2013) was used [41].

\section{Scenario A: "uniform expansion"}

In scenario $\mathrm{A}$, the total corn ethanol amount was increased from 12.5 billion gallons to 24.3 billion gallons. For each year beyond 2013, the corn yield in each state was increased by $1.0 \%$ of the 2013 yield (not compounded). Thus, by 2025, the corn yield was $12 \%$ higher than the 2013 yield in each state. Also, the ethanol yield was increased linearly from 2.8 gal ethanol/bushel in 2013 to $3.0 \mathrm{gal} /$ bushel in 2025 . Finally, the amount of water used within corn ethanol production plants was linearly reduced from $2.7 \mathrm{~L} / \mathrm{L}$ in 2013 to $2.43 \mathrm{~L} / \mathrm{L}$ in 2025.

\section{Scenario B: "50\% expanded irrigation"}

In scenario $B$, the calculation process for the first 12.5 billion gallons of corn ethanol is identical to that used in scenario A. For the additional 11.8 billion gallons of corn ethanol, it is assumed that $50 \%$ of the additional corn comes from irrigated cropland and 50\% comes from non-irrigated cropland. The total water use in each state is the sum of the water used to produce the first 12.5 billion gallons of ethanol (from both irrigated and nonirrigated land in each state's 2013 pattern) and the water used to produce an additional 11.8 billion gallons of ethanol (from both irrigated and non-irrigated land in a $50 / 50$ pattern). Lastly, the water intensity of ethanol produced in a given state is calculated by dividing the total water use by the ethanol production in that state.

\section{Scenario C: "Midwest expansion"}

In scenario $C$, the calculation process for the first 12.5 billion gallons of corn ethanol is identical to that used in scenarios A and B. All corn required for the additional 11.8 billion gallons of ethanol is assumed to be produced from cropland in the top 12 corn-producing states. It is also assumed that the fraction of irrigated corn acreage in each of these 12 states will increase by 10 percentage points. Thus, the water intensity of corn ethanol will increase in each state in accordance with the extent of irrigation. The water intensity of the remaining 17 corngrowing states is unchanged from the baseline scenario.

\section{Results and discussion}

Before discussing the modeling results, three caveats related to corn yields should be mentioned. First, the state-specific corn yields in the baseline case represent a weighted average of yields from irrigated and nonirrigated land. Because the NASS database does not provide separate yields for irrigated and non-irrigated cropland for most states, the same average yields (with escalation) were used in the future-year scenarios, regardless of changes in irrigation patterns. Second, it is generally accepted that corn is currently being grown on lands that are best suited for maximum yields. Thus, expansion of corn cropping into other areas (including Conservation Reserve Program (CRP) lands) would be expected to reduce yields. Third, the demand for additional corn ethanol is expected to increase the practice of continuous corn cropping and decrease rotational cropping that is currently most common. There is evidence that overall corn yields will decline with greater use of continuous cropping [43]. The net effect of these three factors is unknown, though perhaps not very large, as they partially offset each other. Higher yields might be expected with greater use of irrigation, but lower yields would be expected from continuous corn cropping and expansion into less productive lands. Overall, these limitations are not considered so great as to prevent achievement of our primary objective, which is to investigate potential water requirements of expanding corn ethanol to provide for nationwide E20 fuel by 2025.

\section{Water intensity and total water use-baseline scenario}

In the baseline scenario, it is assumed that the water use efficiency is the same in all ethanol plants, namely, 2.7 $\mathrm{L} / \mathrm{L}$ [44]. Thus, differences in the overall external water requirements of corn ethanol among the states (ignoring natural precipitation) are determined solely by variations in irrigation intensity. Crop production, ethanol production, and water use data for each of the 29 corn-growing states included in the 2013 baseline scenario are presented in Table 3. Similar data for all four scenarios are provided in the Additional file 1. 


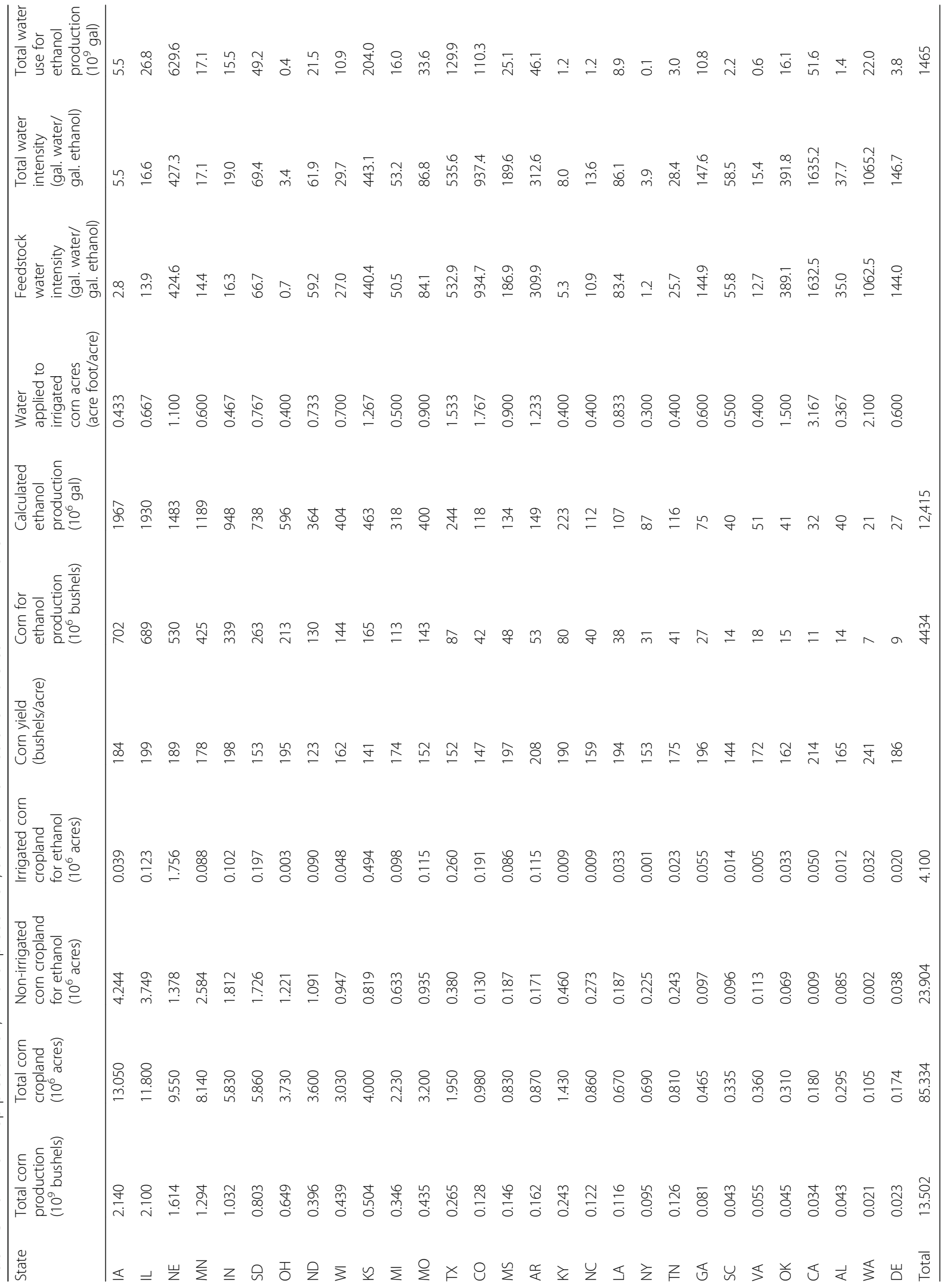


Graphical summaries of water intensity and total water usage for corn ethanol in the top 12 corn-growing states under the baseline scenario are shown in Fig. 3. The total water requirements in these states vary by over two orders of magnitude. It is also seen that in general, the trends of water intensity and total water usage among these 12 states are similar. Two states stand out because of their dramatically higher water use-Nebraska (NE) and Kansas (KS). This results from the high percentage of corn acreage that is irrigated in these two states: $56 \%$ in $\mathrm{NE}$ and $38 \%$ in KS. Two other states (not included in the top 12) having high irrigation percentages are Texas (TX) and Colorado (CO), at 41 and 59\%, respectively. This leads to corn ethanol water intensity values of $536 \mathrm{~L} / \mathrm{L}$ in TX, and $937 \mathrm{~L} / \mathrm{L}$ in $\mathrm{CO}$ (see Table 3). The state with the highest corn ethanol water intensity is California (CA), at $1635 \mathrm{~L} / \mathrm{L}$, although very little corn is produced in CA.

To assess the reasonableness of our baseline water intensity estimates, we compared these results with values published in the literature [20,33]. As shown in Table 4, most of our results are in good agreement with those of Chiu et al., generally being within 20$30 \%$ of each other. Similarly, good agreement is noted with the "blue water" results from Mekonnen and Hoekstra. Inconsistencies of the magnitude seen in Table 4 are expected due to differences in agricultural data sources, time periods, simplifying assumptions, and calculation methods. The overall good agreement between our water intensity results (which were calculated using a relatively simple approach) and those of Chiu et al. and Mekonnen and Hoekstra (which were derived using more sophisticated modeling approaches) provides confidence that our baseline scenario is reasonable.

The total water intensity of corn ethanol consists of two components: feedstock production and fuel production. The relative contributions of these two components in the baseline scenario for the top 12 corn-growing states are depicted in Fig. 4. This illustrates that in states with considerable irrigation-such as NE and KS-almost all of the water intensity is attributable to feedstock production. In states where very little irrigation is used-such as Iowa (IA) and Ohio (OH) - the total water intensity is more evenly divided between feedstock production and fuel production. These data also suggest that improving irrigation efficiency is a more effective way to reduce the total water requirements of corn ethanol than is improving water efficiency within corn ethanol plants.

\section{Water intensity and total water use-future scenarios}

Water intensity results for each of the 29 corn-growing states were calculated for the three future-year scenarios defined above. Complete numerical results are available in the Additional file 1 that accompanies this paper. These results are also presented in Fig. 5a, in the form of "heat maps," to illustrate the differences among the four scenarios. For the top 12 corn-growing states, these water intensity results are also depicted in Fig. 6a.

Comparing scenario A (uniform expansion) with the baseline shows a reduction in water intensity of approximately $16 \%$ in each state. This is a consequence of the assumed increase in corn yield and decrease in biorefinery water usage between the baseline year and 2025 . However, total volumetric water usage in scenario A increased by 908 billion gallons $\left(3.44 \times 10^{12} \mathrm{~L}\right)$, or $62 \%$. Due to the assumption of "uniform expansion" in scenario $\mathrm{A}$, the water increase was largest in states that already had significant irrigation in the baseline case, notably NE, KS, TX, CO, and SD.

In scenario B (50\% expanded irrigation), water intensity increased significantly in nearly every state, with the exception of those where a large fraction of the corn acreage was already irrigated in the baseline case (NE, KS, TX, CO, AR, CA, and WA). This can be seen in Fig. 5a, where most states (other than the aforementioned exceptions) show a darkening in color under scenario $\mathrm{B}$, indicating an increase in water intensity. [The

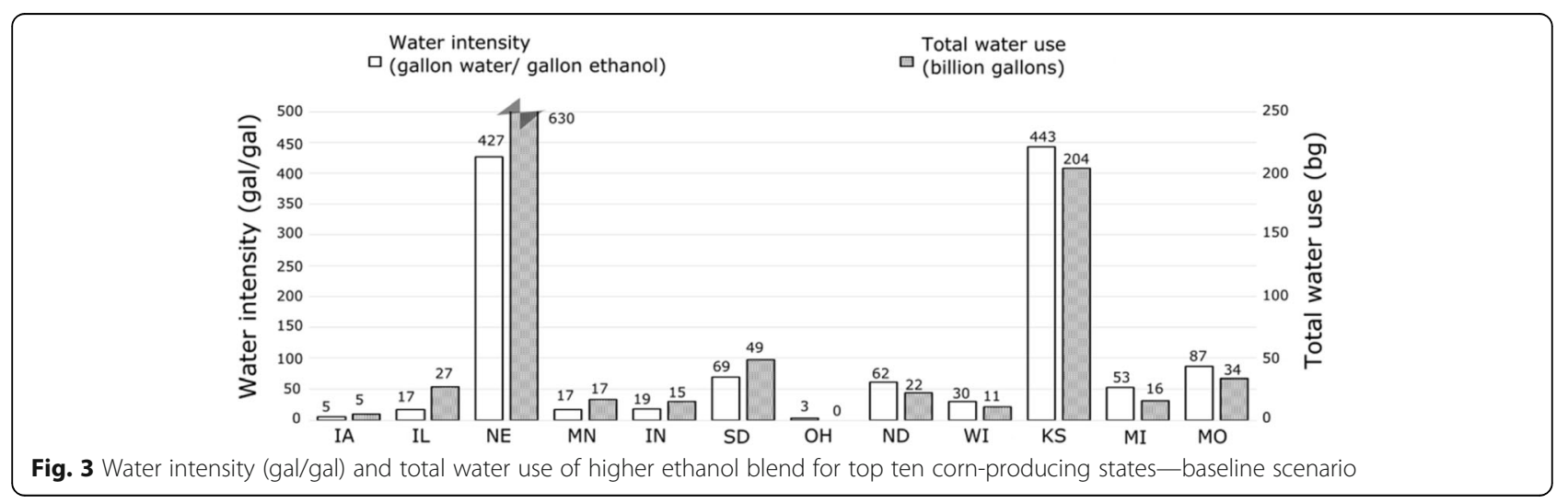


Table 4 Comparison of current study baseline (2013) water intensity $(L / L)$ with literature values

\begin{tabular}{llll}
\hline State & $\begin{array}{l}\text { Current study } \\
\text { baseline (2013) }\end{array}$ & $\begin{array}{l}\text { Chiu }^{\mathrm{a}} \\
(2007)\end{array}$ & $\begin{array}{l}\text { Mekonnen and } \\
\text { Hoekstrab }^{\mathrm{b}} \text { (1996-2005) }\end{array}$ \\
\hline IA & 5 & 6 & 4 \\
MN & 17 & 11 & 10 \\
NE & 427 & 501 & 445 \\
IL & 17 & 19 & 13 \\
IN & 19 & 17 & 16 \\
SD & 69 & 96 & 39 \\
OH & 3 & 5 & 0 \\
ND & 62 & 59 & 53 \\
WI & 30 & 26 & 8 \\
KS & 443 & 528 & 618 \\
MI & 53 & 47 & 32 \\
MO & 87 & 57 & 64 \\
CO & 937 & 1176 & 829 \\
KY & 8 & 7 & 5 \\
TN & 28 & 10 & 9 \\
GA & 148 & 128 & 166 \\
CA & 1635 & 2138 & 1027 \\
\hline
\end{tabular}

Water embodied in ethanol (We) values from Chiu et al. [20]

bBlue water values from Appendix III of Mekonnen and Hoekstra [33]

high water intensities (dark color) shown in CA and Washington (WA) are accurate, but somewhat deceptive, as the total amounts of corn produced in these states are very small.]

The water intensities of the top 12 corn-producing states shown in Fig. 6a clearly illustrate the increased values in scenario $B$ compared to baseline in most cases but show a sharp decline for NE. This is because the baseline scenario includes $56 \%$ irrigated land in NE. Thus, scenario B, in which $50 \%$ of the additional corn is grown on irrigated land, actually represents a water reduction case in NE.
The total water volume required in scenario B increased substantially in every state, as shown by the darkening colors of Fig. 5b, with a total increase of 2366 billion gallons $\left(8.96 \times 10^{12} \mathrm{~L}\right)$, or $161 \%$ as compared to baseline. This consistent increase in total water requirement for each of the top 12 states under scenario B is also clearly seen in Fig. 6b. Particularly sharp increases in water usage are seen in states that have very little irrigation under the baseline scenario-such as IA, IL, MN, and $\mathrm{OH}$. This is because under scenario $\mathrm{B}, 50 \%$ of the additional ethanol in 2025 is derived from corn grown on irrigated acreage.

In scenario $C$, all increased corn production (and increased irrigation) was restricted to the 12 Midwestern states. The water intensity values were found to increase significantly in most of these states, with the exception of NE and KS, which already had high water intensities in the base case (see Fig. 6a). For the remaining 17 states, modest decreases in water intensity are seen, as in scenario A, due to the assumed increase in corn yield and decrease in bio-refinery water usage. However, the total water volume requirement of scenario $\mathrm{C}$ increased by 1195 billion gallons $\left(4.52 \times 10^{12} \mathrm{~L}\right)$, or $82 \%$ as compared to the baseline, due to the assumed 10 percentage point increase in irrigated acres in each of the 12 Midwestern states. As shown in Fig. 6b, these water increases are especially large in NE and KS, although significant increase are also seen in all the other states.

While we have defined and investigated the potential water requirements of three future-year scenarios involving increased ethanol production, it is not clear that any of these scenarios accurately represents future developments. However, taken together, these scenarios present a likely range of possibilities. Of these three, scenario A predicts the smallest increase in total water requirements, while scenario $\mathrm{B}$ predicts the largest increase. However, scenario $\mathrm{C}$, which presents a "middle ground" approach, may be more likely, as it reasonably assumes that most of the additional corn needed to

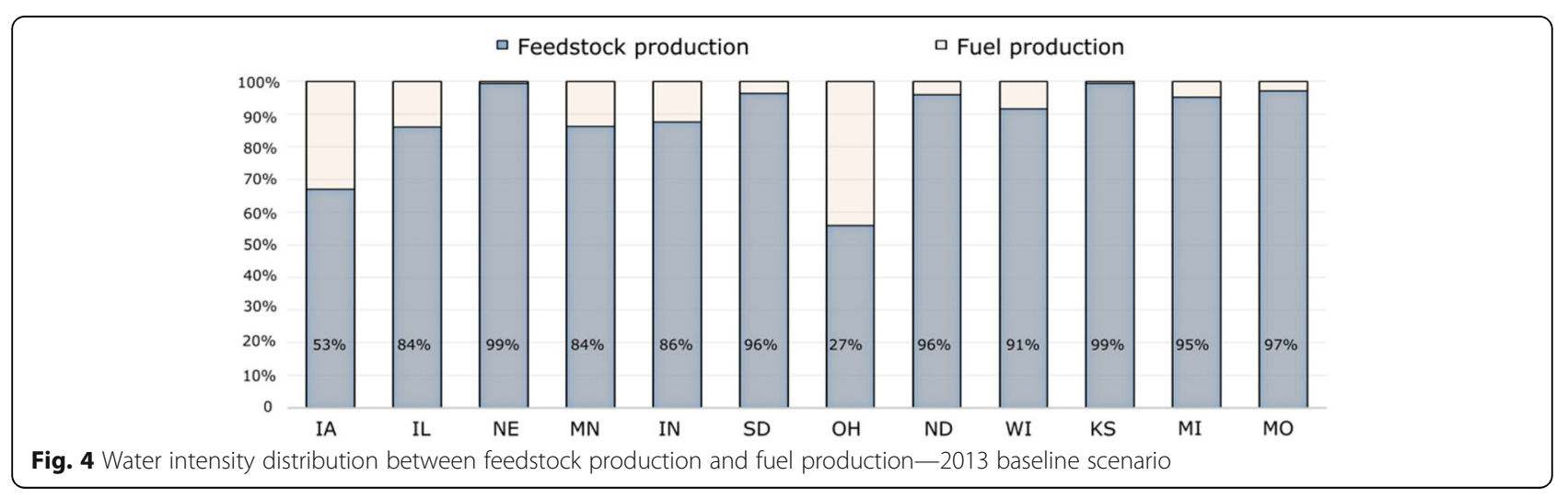



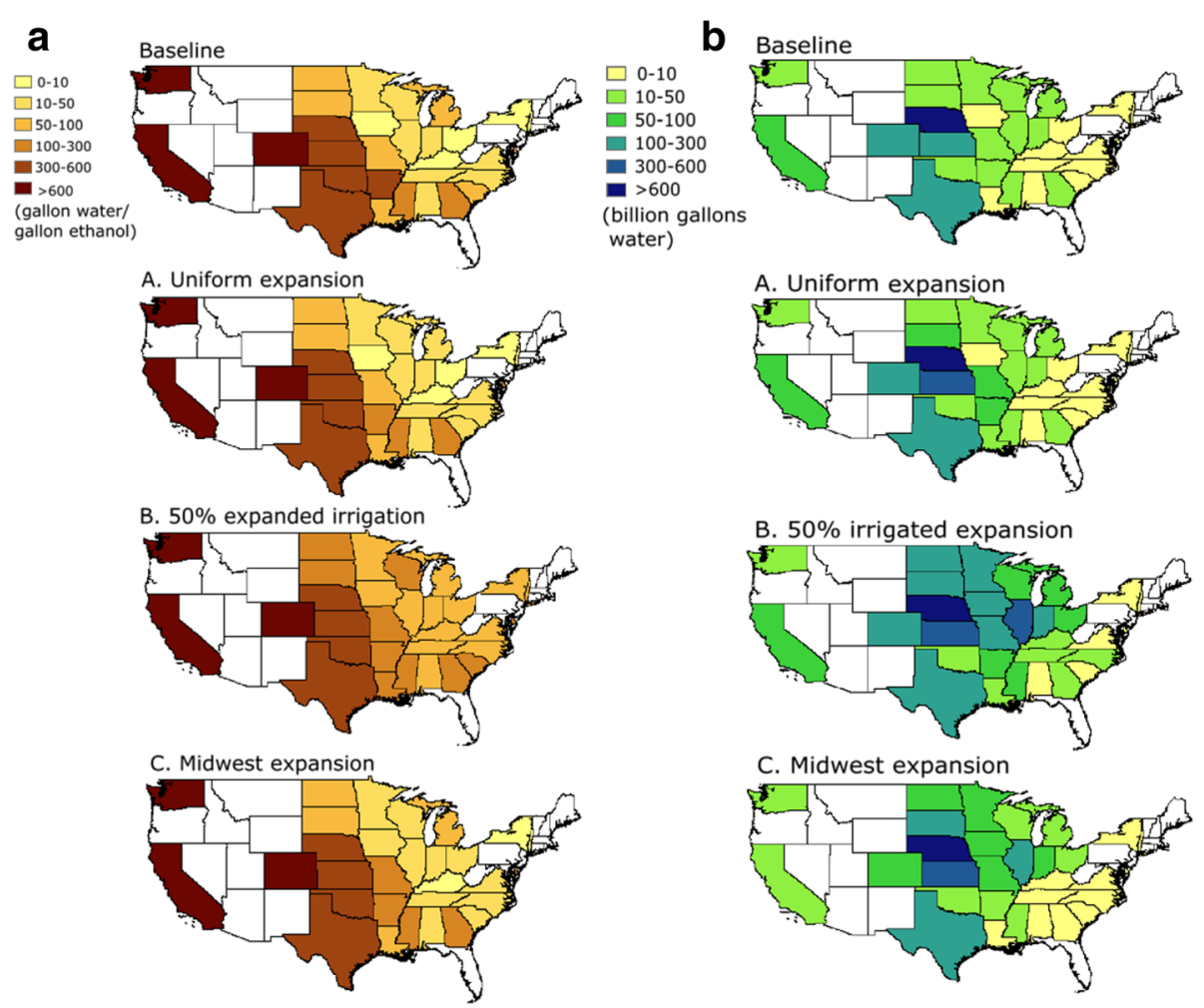

Fig. 5 a Water intensity of corn ethanol production and $\mathbf{b}$ total water required for increased corn ethanol production

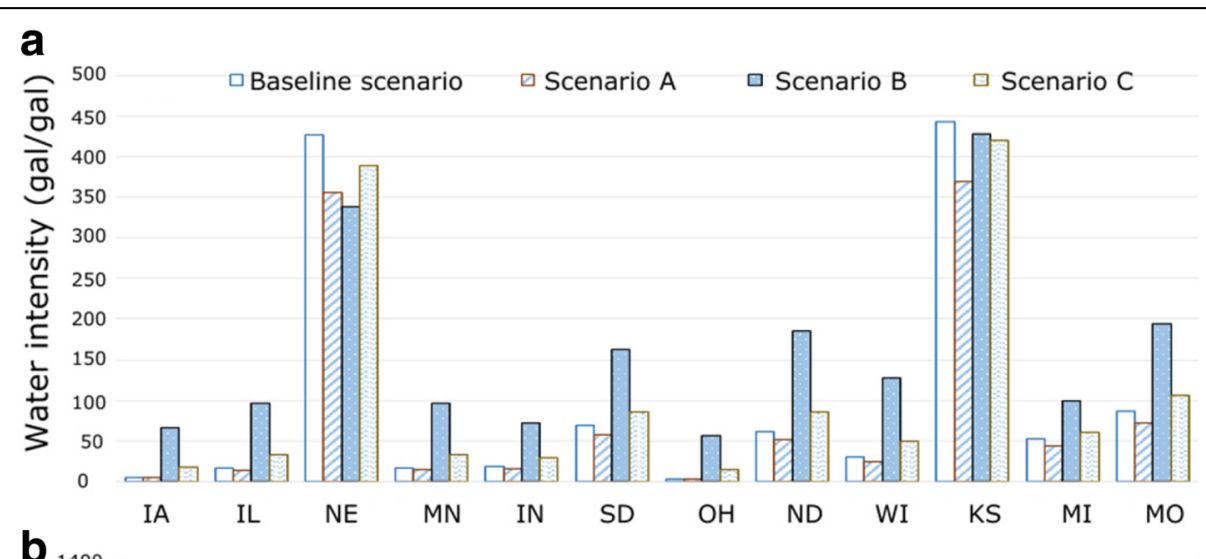

$\mathbf{b}_{1400}$

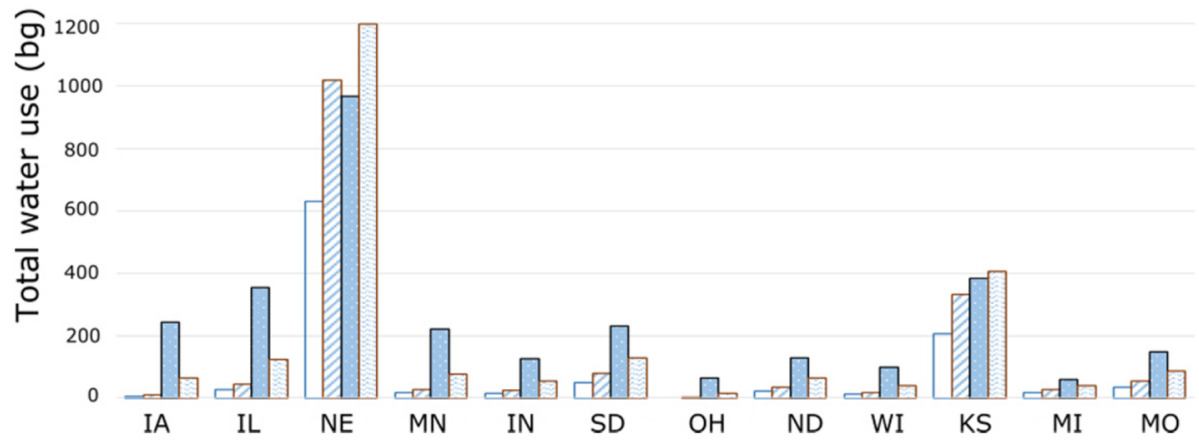

Fig. 6 a Water intensity of corn ethanol in the top 12 corn-growing states. b Total water use attributed to corn ethanol in the top 12 corn-growing states. Comparison of 2013 baseline and three 2025 scenarios 
produce 24.3 billion gallons of ethanol in 2025 will come from Corn Belt states.

From the standpoint of water policy and management, it is important to understand the environmental and ecological impacts of these increased water requirements. For example, withdrawing and consuming a given quantity of water is likely to have greater impacts in Kansas than in Ohio. Assessing these impacts is beyond the scope of this study. However, our results do suggest reasons for concern, in that a significant increase in ethanol demand is likely to result in expansion of corn cropping into water-stressed areas, such as those serviced by the diminishing High Plains Aquifer.

\section{Conclusions}

Our modeling exercise revealed several insights into the potential water impacts of projected higher ethanol blend fuels in the USA. First, the water intensity of corn ethanol depends heavily on where the corn is grown. Ethanol produced in regions requiring significant irrigation has water intensity values two orders of magnitude higher than ethanol produced in non-irrigated areas. Secondly, to produce significantly larger volumes of ethanol in the future will increase the water intensity in most states and will increase total water usage amounts everywhere. Water usage is especially high in top cornproducing states that require substantial irrigation. In the three future-year scenarios explored here, it was determined that expanding corn ethanol production from 12.5 billion gallons in 2013 to 24.3 billion gallons in 2025 would increase total water requirements between $62 \%$ (scenario A) and $161 \%$ (scenario B). Finally, to minimize water demands associated with higher corn ethanol production, expanded corn production should be concentrated in areas requiring little irrigation, and efforts should be taken to improve irrigation efficiency.

\section{Additional file}

Additional file 1: Table S1. 2013 Baseline scenario-state-by-state corn production, ethanol production, and water use. Table S2. 2025 scenario A (uniform expansion) - state-by-state corn production, ethanol production, and water use. Table S3. 2025 scenario B (50\% expanded irrigation) - stateby-state corn production, ethanol production, and water use. Table S4. 2025 scenario C (50\% Midwest expansion)—state-by-state corn production, ethanol production, and water use. (DOCX $48 \mathrm{~kb}$ )

\section{Abbreviations}

EIA: Energy Information Administration; EISA: Energy Independence and Security Act; EPA: US Environmental Protection Agency; GAO: Government Accountability Office; GHG: Greenhouse gas; LCA: Life cycle assessment; NASS: National Agricultural Statistics Service; NRC/NAS: National Research Council/National Academies of Science; RFS: Renewable Fuel Standard; USDA: US Department of Agriculture

\section{Funding}

This work was funded in part by the American Petroleum Institute (API). The data collection, analysis, and interpretation were performed by the authors alone. The results and conclusions presented here are those of the authors and do not necessarily reflect those of API. Preparation of the manuscript was done entirely by the authors.

\section{Authors' contributions}

$\mathrm{XL}$ and SKH conceptualized the project objectives and modeling scenarios. $\mathrm{XL}$ obtained the NASS data inputs and constructed the spreadsheet model to calculate the water requirements for each scenario. All three authors contributed to data analysis and writing of the final manuscript. All authors read and approved the final manuscript.

\section{Competing interests}

The authors declare that they have no competing interests.

\section{Publisher's Note}

Springer Nature remains neutral with regard to jurisdictional claims in published maps and institutional affiliations.

Received: 16 December 2016 Accepted: 22 May 2017

Published online: 21 June 2017

References

1. Scarlat N, Dallemand JF, Monforti-Ferrario F, Banja M, Motola V (2015) Renewable energy policy framework and bioenergy contribution in the European Union - an overview from National Renewable Energy Action Plans and Progress Reports. Renewable Sustainable Energy Rev 51:969-985

2. International Energy Agency (2011) Technology roadmap: biofuels for transport. Prepared by: International Energy Agency, Paris

3. Escobar JC, Lora ES, Venturini OJ, Yanez EE, Castillo EF, Almazan O (2009) Biofuels: environment, technology and food security. Renewable Sustainable Energy Rev 13(6-7):1275-1287

4. Hoekman SK (2009) Biofuels in the U.S.-challenges and opportunities. Renew Energy 34:14-22. doi:10.1016/j.renene.2008.04.030

5. Committee on Economic and Environmental Impacts of Increasing Biofuels Production, National Research Council (2011) Renewable fuel standard: potential economic and environmental effects of U.S. biofuel policy. Prepared by: National Academy of Sciences, http://www.nap.edu/catalog. php?record_id=13105. Accessed Aug 2015

6. EPA (2011) Biofuels and the environment: first triennial report to Congress. Prepared by: National Center for Environmental Assessment, Washington. EPA, EPA/600/R-10/183F

7. National Research Council (2008) Water implications of biofuels production in the United States. National Academies Press, Washington D.C

8. U.S. Congress (2007) H.R. 6: Energy Independence and Security Act of 2007. P.L. 110-140http://www.govtrack.us/congress/bill.xpd?bill=h110-6. Accessed Aug 2015

9. Renewable Fuels Association (2016) Renewable Fuels Association - Industry statistics. http://www.ethanolrfa.org/resources/industry/statistics/ \#1454098996531-cff653b6-7b01. Accessed Feb 2017

10. Gruenspecht H (2016) Statement of Howard Gruenspecht, Deputy Administrator, EIA, to U.S. House of Representatives Committee on Energy and Commerce. http://www.eia.gov/pressroom/testimonies/howard_ 06222016.pdf. Accessed Feb 2017

11. U.S. Government Accountability Office (2016) Renewable fuel standard-low expected production volumes make it unlikely that advanced biofuels can meet increasing targets. GAO-17-108

12. U.S. Energy Information Administration (2016) Annual Energy Outlook 2016 — with projections to 2040. U.S. Department of Energy, Washington, DC, http://www.eia.gov/forecasts/aeo/pdf/0383(2016).pdf

13. Hirshfeld DS, Kolb JA, Anderson JE, Studzinski W, Frusti J (2014) Refining economics of U.S. gasoline: octane ratings and ethanol content. Environ Sci Technol 48:11064-11071

14. Leone TG, Anderson JE, Davis RS, Iqbal A, Reese RA, Shelby MH, Studzinski WM (2015) The effect of compression ratio, fuel octane rating, and ethanol content on spark-ignition engine efficiency. Environ Sci Technol 49:10778-10789. doi: 10.1021/acs.est.5b01420 
15. Speth RL, Chow EW, Malina R, Barrett SRH, Heywood JB, Green WH (2014) Economic and environmental benefits of higher-octane gasoline. Environ Sci Technol 48:6561-6568. doi:10.1021/es405557p

16. Anderson JE, DiCicco DM, Ginder JM, Kramer U, Leone TG, Raney-Pablo HE, Wallington TJ (2012) High octane number ethanol-gasoline blends: Quantifying the potential benefits in the United States. Fuel 97:585-594. doi:10.1016/j.fuel.2012.03.017

17. Service RF (2009) Another biofuels drawback: the demand for irrigation. Science 326:517-518

18. Elcock D (2010) Future US water consumption: the role of energy production. J Am Water Resour Association 46(3):447-460

19. Wu M, Zhang Z, Chiu Y-W (2014) Life-cycle water quantity and water quality implications of biofuels. Curr Sustainable Renewable Energy Rep 1:3-10

20. Chiu Y-W, Walseth B, Suh S (2009) Water embodied in bioethanol in the United States. Environ Sci Technol 43(8):2688-2692

21. Wu M, Mintz M, Wang M, Arora S (2009) Water consumption in the production of ethanol and petroleum gasoline. Environ Manage 44:981-997

22. Dominguez-Faus R, Powers SE, Burken JG, Alvarez PJ (2009) The water footprint of biofuels: a drink or drive issue? Environ Sci Technol 43(9):3005-3010

23. Scown CD, Horvath A, McKone TE (2011) Water footprint of U.S. transportation fuels. Environ Sci Technol 45(7):2541-2553

24. Hernandes TAD, Bufon VB, Seabra JEA (2014) Water footprint of biofuels in Brazil: assessing regional differences. Biofuels Bioproducts Biorefining-Biofpr 8(2):241-252

25. Fachinelli NP, Pereira AO (2015) Impacts of sugarcane ethanol production in the Paranaiba basin water resources. Biomass Bioenergy 83:8-16

26. Fingerman KR, Torn MS, O'Hare MH, Kammen DM (2010) Accounting for the water impacts of ethanol production. Environ Res Lett 5(014020):1-7

27. Harto C, Meyers R, Williams E (2010) Life cycle water use of low-carbon transport fuels. Energy Policy 38(9):4933-4944

28. King CW, Webber ME (2008) Water intensity of transportation. Environ Sci Technol 42(21):7866-7872

29. Kreider JF, Curtiss PS (2007) Comprehensive evaluation of impacts from potential, future automotive fuel replacements. Presented at Energy Sustainability 2007

30. Gerbens-Leenes W, Hoekstra AY, van der Meer TH (2009) The water footprint of bioenergy. Proc Natl Acad Sci U S A 106(25):10219-10223

31. Gerbens-Leenes PW, van Lienden A, Hoekstra A, van der Meer T (2012) Biofuel scenarios in a water perspective: the global blue and green water footprint of road transport in 2030. Global Environ Change-Human Policy Dimensions 22(3):764-775

32. Mekonnen MM, Hoekstra AY (2011) The green, blue and grey water footprint of crops and derived crop products. Hydrology Earth Syst Sci 15(5):1577-1600. doi:10.5194/hess-15-1577-2011

33. Mekonnen MM, Hoekstra AY (2010) The green, blue and grey water footprint of crops and derived crop products, Volume 1: Main Report. UNESCO-IHE, Delft, the Netherlands

34. Mishra GS, Yeh S (2011) Life cycle water consumption and withdrawal requirements of ethanol from corn grain and residues. Environ Sci Technol 45:4563-4569

35. Pfister S, Bayer P, Koehler A, Hellweg S (2011) Environmental impacts of water use in global crop production: hotspots and trade-offs with land use. Environ Sci Technol 45(13):5761-5768. doi:10.1021/es1041755

36. Pfister S, Hellweg S (2009) The water "shoesize" vs. footprint of bioenergy. Proc Natl Acad Sci U S A 106(35):E93-E94. doi:10.1073/pnas.0908069106

37. Fingerman KR, Berndes G, Orr S, Richter BD, Vugteveen P (2011) Impact assessment at the bioenergy-water nexus. Biofuels Bioproducts Biorefining-Biofpr 5(4):375-386

38. Jeswani HK, Azapagic A (2011) Water footprint: methodologies and a case study for assessing the impacts of water use. J Cleaner Prod 19(12):1288-1299

39. (2015) National Agricultural Statistics Service, U.S. Department of Agriculture. http://www.nass.usda.gov/Quick_Stats/. Accessed 3 Aug 2015

40. Renewable Fuels Association (2014) Fueling a nation: feeding the world. The role of the U.S. ethanol industry in food and feed production. Prepared by: Renewable Fuels Association, Washington, DC. http://www.ethanolrfa. org/wp-content/uploads/2015/09/9864ff506e6519057b t5m6brouu.pdf

41. Mueller S (2010) Detailed Report: 2008 National Dry Mill Corn Ethanol Survey. Prepared by: Univ. Illinois, Chicago, http://ethanolrfa.3cdn.net/ 2e04acb7ed88d08d21_99m6idfc1.pdf
42. Hoekstra AY, Chapagain AK, Aldaya MM, Mekonnen MM (2011) The water footprint assessment manual: setting the global standard. Earthscan, London

43. Pikul JL Jr, Hammack L, Riedell WE (2015) Corn yield, nitrogen use, and corn rootworm infestation of rotations in the Northern Corn Belt. Agronomy J 97:854-863

44. Wang M, Wu M, Huo G (2007) Life-cycle energy and greenhouse gas emission impacts of different corn ethanol plant types. Environ Res Lett 2(024001):1-13

\section{Submit your manuscript to a SpringerOpen ${ }^{\circ}$ journal and benefit from:}

- Convenient online submission

- Rigorous peer review

- Open access: articles freely available online

- High visibility within the field

Retaining the copyright to your article

Submit your next manuscript at $>$ springeropen.com 